\title{
Pengaruh harga kualitas produk dan citra merek brand image terhadap keputusan pembelian motor
}

\author{
Dedhy Pradana ${ }^{1}$, Syarifah Hudayah ${ }^{2}$, Rahmawati ${ }^{3}$ \\ Fakultas Ekonomi dan Bisnis Universitas Mulawarman, Samarinda. \\ ${ }^{1}$ Email: dedhypradana91@gmail.com \\ ${ }^{2}$ Email: syarifah.hudayah@feb.unmul.ac.id \\ ${ }^{3}$ Email: rahmawati@feb.unmul.ac.id
}

\begin{abstract}
Abstrak
Tujuan penelitian ini adalah untuk menganalisis faktor-faktor yang berpengaruh bagi konsumen dalam membuat keputusan pembelian. Variabel independen terdiri dari Harga $\left(\mathrm{X}_{1}\right)$, Kualitas Produk $\left(\mathrm{X}_{2}\right)$ dan Citra Merek $\left(\mathrm{X}_{3}\right)$. Variabel dependen adalah Keputusan Pembelian motor Honda Beat di Samarinda. Sampel berjumlah 78 responden yang diambil menggunakan teknik Insidental Sampling. Analisis yang digunakan adalah analisis regresi berganda, hasilnya yaitu $\mathrm{Y}=9.619+0,255 \mathrm{X} 1+$ $0,068 X 2+0,179 X 3$. Berdasarkan Uji F dan Uji t, hasil yang diperoleh bahwa variable Harga, Kualitas Produk dan citra merek berpengaruh positif dan signifikan terhadap keputusan pembelian. Dalam penelitian ini diperoleh nilai koefisien determinasi $\left(\mathrm{R}^{2}\right)$ sebesar 0,208 artinya model koefisien determinasi bagus. Hal ini menunjukkan bahwa 20,80\% keputusan pembelian konsumen terhadap motor Honda Beat di Samarinda dipengaruhi oleh variasi dari ketiga variable independen yaitu atribut produk, harga dan citra merek. Sedangkan sisanya 79,20\% dipengaruhi oleh variabel-variabel lainnya yang tidak diteliti.
\end{abstract}

Kata Kunci: Harga; kualitas produk; citra merek; keputusan pembelian

\section{The influence of price of product quality and brand image of brand image on motor purchasing decision}

\begin{abstract}
The purpose of this research was to analyze the factors that have influences toward consumers in the making of purchasing decision. The independent variables of this research consist of Price $\left(X_{1}\right)$, Product Quality $\left(X_{2}\right)$ and Brand Image $\left(X_{3}\right)$. Dependent variable is Purchase Decision of Honda Beat motorcycle in Samarinda. Sample amounted to 78 respondents taken using Incidental Sampling technique. The analysis used is multiple regression analysis, the result is $Y=9.619+0,255 X 1+$ $0,068 X 2+0,179 X 3$. Based on F test and t test, the results obtained that the variable Price, Product Quality and brand image have a positive and significant impact on purchasing decisions. In this study obtained the value of coefficient of determination (R2) of 0.208 means the model coefficient of determination good. This shows that 20,80\% consumer purchase decision to motor Honda Beat in Samarinda influenced by variation from three independent variable that is product attribute, price and brand image. While the remaining 79.20\% influenced by other variables that are not researched.
\end{abstract}

Keywords: Price; product quality; brand image; purchasing decisions 


\section{PENDAHULUAN}

Sebuah keputusan pembelian yang dilakukan oleh seorang konsumen dilakukan atas dasar keinginan dan kebutuhannya terhadap suatu produk dan banyak faktor yang dapat mendasari keputusan tersebut. Harga, kualitas produk dan citra merek yang ditawarkan suatu perusahaan dapat menjadi faktor yang dipertimbangkan konsumen dalam membeli sebuah motor. Kualitas produk merupakan salah satu faktor yang menjadi pertimbangan penting didalam keputusan pembelian pelanggan, ada yang berani mengeluarkan uang yang cukup mahal asalkan kualitas terjamin. Cara untuk meciptakan merek yang baik menurut logika, adalah dengan menciptakan produk yang kualitasnya lebih baik. Selain dari sisi harga dan kualitas produk, keputusan pembelian sebuah motor juga tidak terlepas dari faktor citra merek (brand image) dari produk tersebut. citra merek adalah sekumpulan asosiasi merek yang terbentuk dibenak konsumen. Karena itu sikap dan tindakan konsumen terhadap suatu merek sangat ditentukan oleh citra merek tersebut, dengan kata lain citra merek (brand image) adalah salah satu unsur penting yang mendorong konsumen untuk membeli sebuah produk. Semakin baik citra merek (brand image) yang melekat pada produk tersebut maka konsumen akan semakin tertarik untuk membeli, karena konsumen beranggapan bahwa suatu produk dengan citra merek yang sudah terpercaya lebih memberikan rasa aman ketika konsumen itu menggunakan produk yang akan dibeli.

Honda sebagai merek yang telah dikenal berupaya menghadirkan jawaban akan kebutuhan masyarakat yang kerap berkembang seiring meningkatnya taraf dan kualitas hidup. Honda juga selalu mengembangkan produk-produk yang melebihi ekspektasi, seiring dengan semangat berkontribusi secara signifikan dalam pengembangan industri otomotif motor matic Indonesia. Kepopuleran produk Honda ini sangat diakui bahakan dari zaman dulu di kota Samarinda apabila berpergian menggunakan motor merk apapun orang tua dulu menyebutnya be "Honda" inilah yang membuat citra merk Honda sangat kuat. Fenomena persaingan yang sangat kompetitif inilah yang membuat peneliti ingin mengetahui apakah faktor harga, kualitas produk, dan citra merek dapat menjadi faktor yang dipertimbangankan konsumen dalam mengambil keputusan untuk membeli Motor Matic Honda Beat.

\section{Kajian Pustaka}

Harga adalah nilai suatu barang yang dinyatakan dengan uang. (Alma, 2004:169). Menurut Tandjung (2004:78), harga merupakan jumlah uang yang telah disepakati oleh calon pembeli dan penjual untuk ditukar dengan barang atau jasa dalam transaksi bisnis normal.

Harga merupakan salah satu faktor penentu dalam pemilihan merek yang berkaitan dengan keputusan pembelian konsumen. Ketika memilih diantara merek-merek yang ada konsumen akan mengevaluasi harga secara tidak langsung dengan membandingkan beberapa standar harga sebagai referensi untuk melakukan transaksi pembelian. Harga adalah salah satu unsur dalam bauran pemasaran yang mempunyai peranan penting bahkan sangat menentukan keberhasilan suatu kegiatan pemasaran.

Menurut Kotler dan Amstrong (2008:278) indikator harga adalah sebagai berikut:

a) Harga terjangkau oleh kemampuan daya beli konsumen.

b) Kesesuaian antara harga dengan kualitas.

c) Harga memiliki daya saing dengan produk lain yang sejenis.

Menurut Kotler (2008:272), kualitas produk adalah karakteristik produk atau jasa yang tergantung pada kemampuannya untuk memuaskan kebutuhan pelanggan yang dinyatakan atau diimplikasikan. Sedangkan definisi kualitas produk menurut Tjiptono (2006:51) adalah suatu kondisi dinamis yang berhubungan dengan produk, jasa, manusia, proses, dan lingkungan yang memenuhi atau melebihi harapan. Kualitas sering dianggap sebagai ukuran relatif kebaikan suatu produk atau jasa yang terdiri atas kualitas desain dan kualitas kesesuaian.

Menurut Tjiptono dan Diana (2003:27) indikator kualitas produk adalah sebagai berikut:

a) Daya tahan mesin yang tangguh untuk menempuh perjalanan.

b) Konsumsi bahan bakar irit.

c) Suku cadang berkualitas. 
Citra merek merupakan keseluruhan persepsi terhadap produk atau merek yang dibentuk dari informasi dan pengalaman masa lalu terhadap produk atau merek itu. (Sutisna, 2003:83). Definisi lain dari citra merek adalah kesan yang diperoleh sesuai dengan pemahaman seseorang tentang sesuatu. (Alma, 2004:375)

Citra merek (brand image) merupakan serangkaian asosiasi yang ada dalam benak konsumen terhadap suatu merek. Hubungan terhadap suatu merek akan semakin kuat jika berdasarkan pengalaman dan berbagai informasi. Sedangkan definisi citra merek menurut Tjiptono (2005:49) adalah deskripsi tentang asosiasi dan keyakinan konsumen terhadap merek tertentu.

Menurut Low dan Lamb (2000:4) indikator citra merek adalah sebagai berikut:

a) Merek dikenal oleh masyarakat luas.

b) Merek menambah citra diri penggunanya.

c) Merek memiliki ciri khas yang berbeda dengan merek lain.

Menurut Kotler dan Amstrong (2008:181) mengemukakan bahwa keputusan pembelian konsumen adalah membeli merek yang paling disukai.

Menurut Kotler dan Keller (2009:240) menyatakan keputusan pembelian adalah keputusan konsumen mengenai preferensi atas merek-merek yang ada di dalam kumpulan pilihan.

Menurut Kotler dan Armstrong (2008:181) indikator keputusan pembelian adalah sebagai berikut:

a) Kemantapan membeli setelah mengetahui informasi produk.

b) Memutuskan membeli karena merek yang paling disukai.

c) Membeli karena sesuai dengan keinginan dan kebutuhan.

d) Membeli karena mendapat rekomendasidari orang lain.

\section{METODE}

Jenis penelitian yang digunakan dalam skripsi ini adalah jenis penelitian deskriptif kuantitatif. Jenis penelitian ini bertujuan untuk menganalisa dan menarik kesimpulan mengenai keadaan objek yang diteliti berdasarkan fakta yang terdapat dalam perusahaan.

\section{Hasil analisis}

Berdasarkan hasil penelitian dan permasalahan yang diketahui dalam penelitian pada konsumen yang membeli Motor Matic Honda Beat, maka dalam analisis ini akan dibahas mengenai Pengaruh Harga, Kualitas Produk dan Citra Merek (Brand Image) Terhadap Keputusan Pembelian Motor Matic Honda Beatdi Kota Samarinda.

$$
\mathrm{Y}=9.619+0,255 \mathrm{X}_{1}+0,068 \mathrm{X}_{2}+0,179 \mathrm{X}_{3}
$$

Persamaan regresi tersebut dapat dijelaskan sebagai berikut:

1. Konstanta sebesar 9.619; artinya jika pengaruh harga $\left(\mathrm{X}_{1}\right)$, kualitas barang $\left(\mathrm{X}_{2}\right)$, dan Citra Merek $\left(\mathrm{X}_{3}\right)$ nilainya adalah 0 , maka keputusan pembelian barang $(\mathrm{Y})$ nilainya adalah 9.619.

2. Koefesien regresi variabel pengaruh harga $\left(\mathrm{X}_{1}\right)$ sebesar 0,255 ; artinya jika variabel independen lain nilainya tetap dan pengaruh harga $\left(\mathrm{X}_{1}\right)$ mengalami kenaikan $1 \%$ maka, keputusan pembelian barang (Y) akan mengalami kenaikan sebesar $0.255 \%$. Koefesien bernilai positif artinya pengaruh harga berpengaruh positif terhadap keputusan pembelian barang, semakin besar pengaruh harga maka semakin tinggi keputusan pembelian barang.

3. Koefesien regresi variabel kualitas produk $\left(\mathrm{X}_{2}\right)$ sebesar 0.068 ; artinya jika variabel independen lain nilainya tetap dan kualitas produk $\left(\mathrm{X}_{2}\right)$ mengalami kenaikan $1 \%$ maka, keputusan pembelian barang (Y) akan mengalami kenaikan sebesar $0.068 \%$. Koefesien bernilai positif artinya kualitas produk berpengaruh positif terhadap keputusan pembelian barang, semakin besar kualitas produk maka semakin tinggi keputusan pembelian barang.

4. Koefesien regresi variabel citra merek $\left(\mathrm{X}_{3}\right)$ sebesar 0.179 ; artinya jika variabel independen lain nilainya tetap dan citra merek $\left(\mathrm{X}_{3}\right)$ mengalami kenaikan $1 \%$ maka, keputusan pembelian barang (Y) akan mengalami kenaikan sebesar $0.179 \%$. Koefesien bernilai positif artinya citra merek berpengaruh positif terhadap kualitas pembelian barang. semakin besar citra merek maka semakin tinggikeputusan pembelian barang. 
Uji T tersebut dapat di jelaskan sebagai berikut:

Dari hasil uji t tersebut diketahui pengaruh masing- masing variabel bebas yaitu pengaruh harga $\left(\mathrm{X}_{1}\right)$, kualitas produk $\left(\mathrm{X}_{2}\right)$, dan citra merek $\left(\mathrm{X}_{3}\right)$ terhadap variabel terikatnya keputusan pembelian barang (Y) sebagai berikut:

1. Pengaruh harga $\left(\mathrm{X}_{1}\right)$ memiliki nilai signifikansi sebesar 0.002 yang berarti nilainya lebih kecil dari 0.05, maka dapat disimpulkan bahwa pengaruh harga berpengaruh signifikan terhadap keputusan pembelian barang.

2. Kualitas produk memiliki nilai signifikansi sebesar 0.683 yang berarti nilainya lebih besar dari 0.05, maka dapat disimpulkan bahwa kualitas produk tidak berpengaruh signifikan terhadap keputusan pembelian barang.

3. Citra Merek memiliki nilai signifikansi sebesar 0.084 yang berarti nilainya lebih besar dari 0.05 , maka dapat disimpulkan bahwa citra merek tidak berpengaruh signifikan terhadap keputusan pembelian barang.

Dilihat dari tabel 4.18 nilai koefisien korelasi (R) sebesar 0,456 dengan tabel interpretasi koefisien korelasi berada pada posisi di antara 0,800-1,000 yang menunjukkan bahwa hubungan bersifat sangat kuat antara variabel Harga $\left(\mathrm{X}_{1}\right)$, Kualitas Produk $\left(\mathrm{X}_{2}\right)$ dan Citra Merek (Brand Image) $\left(\mathrm{X}_{3}\right)$ terhadap Y (Keputusan Pembelian) Motor Matic Honda Beat di Kota Samarinda.

Untuk mengetahui besarnya pengaruh variabel bebas terhadap variabel terikat adalah dengan mencari $\mathrm{R}$ square atau koefisien determinasi. Nilai $\mathrm{R}^{2}$ sebesar 0,208 . Hal ini berarti $20.80 \%$ variabel dari keputusan pembelian dipengaruhi oleh variabel bebas.Sedangkan sisanya $79.20 \%$ dipengaruhi oleh variabel-variabel lain yang tidak diteliti dalam penelitian ini.

Pada tabel diatas angka R Square adalah 0,208 yaitu hasil kuadrat dari koefisien korelasi $(0,456$ x $0,456=0,208)$. Standar Error of the Estimate adalah 1,258, perhatikan pada analisis deskriptif statitik bahwa standar deviasi nilai keputusan pembelian adalah 1,386 yang jauh lebih besar dari dari standar error, oleh karena lebih besar daripada standar deviasi nilai keputusan pembelian maka model regresi bagus dalam bertindak sebagai predictor keputusan pembelian.

Tabel 1. Hasil Perhitungan Uji F (Uji Serentak)

ANOVA $^{\mathrm{a}}$

\begin{tabular}{rlrrrrr}
\hline Model & & Sum of Squares & df & Mean Square & F & Sig. \\
\hline \multirow{4}{*}{1} & Regression & 30.799 & 3 & 10.266 & 6.484 & $.001^{\mathrm{b}}$ \\
& Residual & 117.162 & 74 & 1.583 & & \\
& Total & 147.962 & 77 & & & \\
\hline
\end{tabular}

a. Dependent Variable: $Y=$ Keputusan Pembelian

b. Predictors: (Constant), X3= Citra Merek (Brand Image), X2= Kualitas Produk, X1 = Pengaruh

Harga

Sumber: Data hasil analisis regresi SPSS versi 20.0

Uji $\mathrm{F}$ dilakukan dengan tingkat kepercayaan 95\% dengan $\alpha=0.05$. Hasil pengujian dengan menggunakan program SPSS versi 20 dapat dilihat pada table 4.19 berikut ini:

Pada bagian ini apakah ada pengaruh yang nyata / signifikan variabel pengaruh harga (X1), kualitas produk (X2), citra merek (X3), secara simultan (bersama-sama) terhadap keputusan pembelian barang (Y) dari output model di atas di dapat $\mathrm{F}$ hitung sebesar 6,484 dengan tingkat signifikan 0,001 $<0.05$ maka regresi dapat di pakai untuk memprediksi keputusan pembelian barang. Setelah diuji dan dibandingkan ternyata $\mathrm{F}$ hitung 6,484 > F Tabel 2.72 maka Ho ditolak dan Ha diterima yang artinya terdapat pengaruh secara signifikan dari variabel bebas yaitu pengaruh harga, kualitas produk dan citra merek (brand image) terhadap keputusan pembelian motor matic HondaBeat di Kota Samarinda. 


\section{Pembahasan}

Dari hasil perhitungan diperoleh persamaan regresi berganda variabel Harga $\left(\mathrm{X}_{1}\right)$, Kualitas Produk $\left(\mathrm{X}_{2}\right)$ dan Citra Merek (Brand Image) $\left(\mathrm{X}_{3}\right)$ akan memberikan pengaruh terhadap Y (Keputusan Pembelian) Motor Matic Honda Beat di Kota Samarinda, dengan persamaan sebagai berikut:

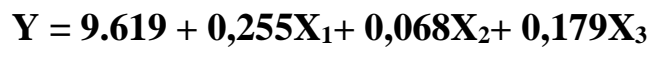

Berdasarkan persamaan regresi berganda di atas menunjukkan bahwa Harga, Kualitas Produk dan Citra Merek (Brand Image) memberikan pengaruh yang positif terhadap keputusan pembelian Motor Honda Beat di Kota Samarinda. Artinya apabila variabel Harga, Kualitas Produk dan Citra Merek (Brand Image) ditingkatkan, maka akan meningkat pula keputusan pembelian Motor Matic Honda Beat di Kota Samarinda.

Variabel Harga, Kualitas Produk dan Citra Merek (Brand Image) secara bersama-sama mempunyai pengaruh yang signifikan terhadap keputusan pembelian. Hal ini didukung oleh hasil nilai F hitung sebesar 6,484 dengan signifikan yang diperoleh 0,001 lebih kecil dari 0,05. Artinya apabila variabel Harga, Kualitas Produk dan Citra Merek (Brand Image) mendapatkan perhatian secara bersama-sama maka akan mampu mendorong konsumen membeli Motor Matic Honda Beat di Kota Samarinda.

Penelitian ini sejalan dengan penelitian yang dilakukan Bella Gusniar (2014) yang berjudul "Pengaruh Citra merek, Harga dan Kualitas Produk Terhadap Keputusan Pembelian Hand \& Body Lotion Merek Citra (Studi Kasus Mahasiswa Universitas Dian Nuswantoro Semarang)”. Dan didikung oleh teori sebagai berikut.

Harga merupakan salah satu faktor yang dipertimbangkan konsumen untuk menentukan keputusan pembelian terhadap suatu produk. Menurut Kotler dan Armstrong (2012:314) harga adalah sejumlah uang yang dibebankan atas suatu produk atau jasa, atau nilai yang ditukar konsumen atas manfaat-manfaat karena memiliki atau menggunakan produk atau jasa tersebut. Pengaruh harga terhadap keputusan pembelian sangatlah penting, kerena tingkat harga yang ditetapkan oleh perusahaan dapat menjadi tolak ukur akan permintaan suatu produk. Penetapan harga yang salah atas suatu produk dapat mengakibatkan jumlah penjualan pada suatu produk tidak dapat maksimal yang mengakibatkan penjualan menurun dan pangsa pasarnya berkurang.

Kualitas produk adalah keseluruhan ciri serta dari suatu produk atau pelayanan pada kemampuan untuk memuaskan kebutuhan (Kotler, 2005:49) Definisi lain kualitas adalah suatu kondisi dinamis yang berhubungan dengan produk, jasa, manusia, proses, dan lingkungan yang memenuhi atau melebihi harapan (Tjiptono,2006:51). Kualitas produk merupakan salah satu faktor yang menjadi pertimbangan penting didalam keputusan pembelian pelanggan, ada yang berani mengeluarkan uang yang cukup mahal asalkan kualitas terjamin.

Selain dari sisi harga dan kualitas produk, keputusan pembelian sebuah motor juga tidak terlepas dari faktor citra merek (brand image) dari produk tersebut. Menurut Rangkuti (2009:90) citra merek adalah sekumpulan asosiasi merek yang terbentuk dibenak konsumen.

Setelah itu pengujian hipotesis menggunakan uji t maka hasil yang diperoleh untuk pengujian parsial dari hasil perhitungan adalah sebagai berikut:

a. Pengaruh Harga terhadap Keputusan Pembelian Motor Beat di Kota Samarinda

Harga dengan indikator harga terjangkau oleh daya beli konsumen, Harga dengan indikator harga terjangkau oleh daya beli konsumen, kesesuaian harga dengan kualitas dan harga memiliki daya saing dengan produk lain yang sejenis telah mampu mendorong keputusan pembelian Motor Matic Honda Beat di Kota Samarinda.

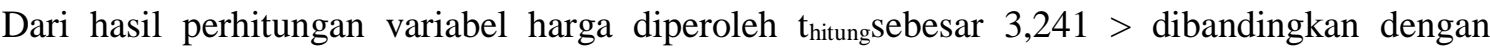

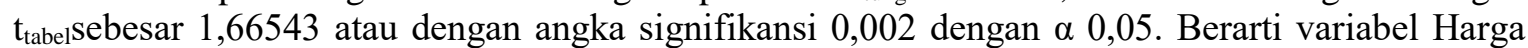
$\left(\mathrm{X}_{1}\right)$ memiliki pengaruh positif terhadap Y (Keputusan Pembelian) Motor Matic Honda Beat di Kota Samarinda. Dengan demikian Hipotesis $1\left(\mathrm{H}_{1}\right)$ diterima.

Penetapan harga yang tepat akan mendapat perhatian yang besar dari konsumen. Jika harga yang ditetapkan oleh perusahaan tepat dan sesuai dengan daya beli konsumen maka konsumen tidak ragu untuk memilih produk tersebut. Sebuah Motor mempunyai suatu keunggulan yang 
diperoleh dengan adanya efisien biaya berdasarkan pada nilai pasarnya. Artinya jika Motor Matic Honda Beat terjual kembali, maka memiliki nilai jual yang lebih baik dibandingkan Motor sejenis lainnya.

b. Pengaruh Kualitas Produk terhadap Keputusan Pembelian Motor Matic Honda Beat di Kota Samarinda.

Kualitas produk dengan indikator daya tahan mesin Motor yang tangguh dalam menempuh perjalanan, suku cadang yang berkualitas serta konsumsi bahan bakar yang irit menjadi nilai jual yang dapat menarik minat konsumen untuk mendorong melakukan pembelian Motor Matic Honda Beat.

Dari hasil perhitungan variabel kualitas produk $\mathrm{t}_{\text {hitung }}$ sebesar $0,410>$ dibandingkan dengan

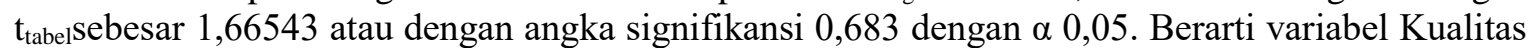
Produk $\left(\mathrm{X}_{3}\right)$ memiliki pengaruh positif terhadap Y (Keputusan Pembelian) Motor Matic Honda Beat di Samarinda. Dengan demikian Hipotesis $2\left(\mathrm{H}_{2}\right)$ diterima.

Suatu produk yang mampu memenuhi harapan konsumen dan mampu meningkatkan kepuasan pelanggan akan membuat produk tersebut laku terjual, meningkatkan pangsa pasar, dan dapat dijual dengan harga yang tinggi akan dinilai bahwa produk tersebut berkualitas yang dimiliki oleh Honda Beat. Mutu atau kualitas produk menjadi salah satu pertimbangan konsumen dalam membeli, kualitas tersebut apakah memberikan manfaat yang besar atau tidak bagi konsumen. Pesaing yang banyak di pasar menuntut perusahaan harus memerhatikan kebutuhan konsumen, serta berusaha memenuhi kebutuhan itu dengan produk yang bermutu tinggi. Kualitas produk memberikan dorongan kepada konsumen untuk menjalin ikatan yang kuat dengan perusahaan.

c. Pengaruh Citra Merek (Brand Image) terhadap Keputusan Pembelian Motor Matic Honda Beat di Kota Samarinda.

Citra merek (brand image) dengan indikator merek Honda dikenal oleh masyarakat luas, merek menambah citra diri penggunanya dan merek Honda memiliki ciri khas yang berbeda dengan merek lain diketahui telah mampu mendorong keputusan pembelian Motor Matic Honda Beat di Samarinda.

Dari hasil perhitungan variabel citra merek diperoleht ${ }_{\text {hitung }}$ sebesar 1,754 > dibandingkan

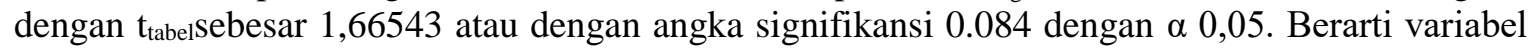
Citra Merek $\left(\mathrm{X}_{3}\right)$ memiliki pengaruh positif terhadap Y (Keputusan Pembelian) Motor Matic Honda Beat di Kota Samarinda. Dengan demikian Hipotesis $3\left(\mathrm{H}_{3}\right)$ diterima.

Citra merek memiliki pengaruh terhadap perilaku konsumen dalam keputusan pembelian. Karena merek merupakan pertimbangan utama dalam pengambilan keputusan oleh para konsumen. Semakin baik citra merek (brand image) yang melekat pada produk tersebutmaka konsumen akan semakin tertarik untuk membeli, karena konsumenberanggapan bahwa suatu produk dengan citra merek yang sudah terpercaya lebih memberikan rasa aman ketika konsumen itu menggunakan produk yang akan dibeli dan semakin naik pula penjualan produk tersebut.

\section{SIMPULAN}

Kesimpulan atas masalah penelitian ini didasarkan atas temuan permasalahan yang teridentifikasi dan tersusun dalam rumusan masalah penelitian. Adapun tujuan dalam penelitian ini adalah untuk menguji pengaruh harga, kualitas produk, citra merek (brand image) terhadap keputusan pembelian motor matic Honda Beat di Kota Samarinda. Menguji pengaruh harga terhadap keputusan pembelian motor matic Honda Beat di Kota Samarinda, Menguji pengaruh kualitas produk terhadap keputusan pembelian motor matic Honda Beat di Kota Samarinda, Menguji pengaruh citra merek (brand image) terhadap keputusan pembelian motor matic Honda Beat di Kota Samarinda.

Dalam penelitian ini yang menjadi populasi adalah masyarakat umum kota Samarinda yang membeli dan menggunakan Motor Matic Honda Beat. Populasi dalam penelitian ini adalah sebanyak 78 karena berdasarkan data yang diperoleh dari pihak informasi dealer Honda PT Nusantara Surya Sakti Samarinda Jalan Slamet Ryadi No 19 Samarinda, konsumen pada bulan Oktober, motor Honda Beat yang terjual mencapai 78 unit.

Data yang di gunakan dalam penelitian ini melalui kuisioner yang dilakukan di Dealer Honda PT Nusantara Surya Sakti Samarinda Jalan Slamet Ryadi No 19 Samarinda. Penelitian ini 
menggunakan Analisis Regresi Berganda dengan pengolahan data menggunakan program SPSS (Statistical Product and Service Solution) versi 20.00.

Variabel Harga $\left(\mathrm{X}_{1}\right)$ mempunyai pengaruh positif terhadap variabel keputusan pembelian (Y) Motor Matic Honda Beat di Kota Samarinda sehingga menerima hipotesis pertama yang artinya harga terjangkau oleh daya beli konsumen, kesesuaian harga dengan kualitas dan harga memiliki daya saing dengan produk lain yang sejenis telah mampu meningkatkan keputusan pembelian Motor Matic Honda Beat di Kota Samarinda.

Variabel Kualitas Produk $\left(\mathrm{X}_{2}\right)$ mempunyai pengaruh positif terhadap variabel keputusan pembelian (Y) Motor Matic Honda Beat di Kota Samarinda sehingga menerima hipotesis kedua yang artinya kualitas produk dengan indikator daya tahan mesin motor yang tangguh dalam menempuh perjalanan, suku cadang yang berkualitas serta konsumsi bahan bakar yang irit menjadi nilai jual yang dapat menarik minat konsumen untuk meningkatkan keputusan pembelian Motor Matic Honda Beat di Kota Samarinda.

Variabel Citra Merek (brand image) $\left(\mathrm{X}_{3}\right)$ mempunyai pengaruh positif terhadap variabel keputusan pembelian (Y) Motor Matic Honda Beat di Kota Samarinda sehingga menerima hipotesis ketiga yang artinya Citra merek (brand image) dengan indikator merek Honda dikenal oleh masyarakat luas, merek menambah citra diri penggunanya dan merek Honda memiliki ciri khas yang berbeda dengan merek lain diketahui telah mampu meningkatkan keputusan pembelian Motor Matic Honda Beat di Kota Samarinda.

\section{DAFTAR PUSTAKA}

Aaker, David A. 1995. Building Strong Brands. The Free Press Publisher. New York

Aaker dan Joachimstahler. 2000. Marketing. Edisi Ketiga. Erlangga, Jakarta.

Alma, Buchari. 2007. Manajemen Pemasaran dan Pemasaran Jasa. Alfabeta. Bandung.

Angipora, Marius. 2002. Dasar-Dasar Pemasaran. Edisi Kedua. PT. Raja Grafindo Persada. Jakarta.

Assauri, Sofjan. 2007. Manajemen Pemasaran. Rajawali Pers. Jakarta.

Fajar, Laksana. 2008. Manajemen Pemasaran. Graha Ilmu. Yogyakarta.

Ghozali, Imam. 2006. Aplikasi Analisis Multivariate Dengan Program SPSS.Undip. Semarang.

Gusniar, Bella. 2014. Pengaruh Citra merek, Harga dan Kualitas Produk Terhadap Keputusan Pembelian Hand \& Body Lotion Merek Citra. Universitas Dian Nuswantoro. Semarang

Husein, Umar. 2004. Metode Penelitian Untuk Skripsi dan Tesis Bisnis.Raja Grafindo Persada. Jakarta

Jiang, Pingjun, Rosenbloom, Bert. 2005 Customer intention to return online: price perception, attribute-level performance, and saticfaction. European Journal of Marketing.

Kalfi, Masri. 2015. Pengaruh Produk dan Harga Terhadap Keputusan Pembelian Perlengkapan Kemping Merek Eiger Di Kota Padang.Universitas Negeri Padang. Padang

Kotler, Philip. 2004. Manajemen Pemasaran 2, Edisi Millenium, PT. Ikrar Mandiri, Jakarta.

Kotler, Philip dan Gary Armstrong. 2008. Prinsip-Prinsip Pemasaran Jilid 1 Edisi Ke-12. Alih Bahasa oleh Bob Sabran. Erlangga. Jakarta.

Kotler, Philip dan Kevin Lane Keller. 2007.Manajemen Pemasaran Jilid 1 Edisi Ke-12. Alih Bahasa oleh Benyamin Molan. Indeks. Jakarta

Lamb, Hair Mc Daniel. 2004. Marketing. Seventh Edition. Thomson. Southwestern.

Monroe. 2003. Pricing Making Profitable Decision. The Mc Graw-Hill Companies. New York

Palmer, Adrian. 2001. Principles of Services Marketing, Third Edition McGraw-Hill Companies, UK (United Kingdom)

Pride, W dan Ferrel. 2005. Marketing Principles. Edisi Terjemahan. Erlangga. Jakarta 
Priyambodo, Ganjar. 2014. Pengaruh Kualitas Produk, Harga dan Promosi Terhadap Keputusan Pembelian Handphone Merek Blackberry. Universitas Dian Nuswantoro. Semarang

Rangkuti, Freddy.2009. Strategi Promosi Yang Kreatif. Edisi Pertama. Gramedia Pustaka Utama. Jakarta

Ridhwan, R. M. 2014. Pengaruh Citra Merek dan Kualitas Produk Terhadap Keputusan Pembelian Motor Honda All New Jazz. Universitas Brawijaya. Malang

Sekaran, Uma. 2009. Metodologi Penelitian Untuk Bisnis. Salemba Empat. Jakarta

Stanton, William. 2001. Prinsip Pemasaran, Terjemahan Sundaru Dadu. Erlangga. Jakarta

Sugiyono. 2010. Statistika Untuk Penelitian. Alfabeta. Bandung.

Sugiyono. 2012. Metode Penelitian Kuantitatif Kualitatif. Alfabeta. Bandung

Suharso, Puguh. 2009. Metode Penelitian Kuantitatif Untuk Bisnis: Pendekatan Filosofi dan Praktis. Cetakan Pertama. Jakarta

Sutisna.2003. Perilaku Konsumen \& Komunikasi Pemasaran. Remaja Rosdakarya. Bandung

Tandjung, J. W. 2004. Marketing Management: Pendekatan Pada Nilai-Nilai Pelanggan. Edisi Kedua. Bayumedia. Malang

Tjiptono, Fandy. 2008. Strategi Pemasaran Edisi Ketiga. Andi Offset. Yogyakarta.

Tjiptono, Fandy dan Anastasia Diana. 2003. Total Quality Management. Edisi Kelima. Andi Offset. Yogyakarta

Wahma, I Gede.2014. Pengaruh Promosi dan Citra Merek Terhadap Keputusan Pembelian MotorHonda Tipe MPV. Universitas Udayana. Denpasar 